\title{
Zonation and correlation of the earliest Ordovician graptolites from Hunjiang, Jilin province, China
}

\author{
WANG XIAOFENG AND BERND-D. ERDTMANN
}

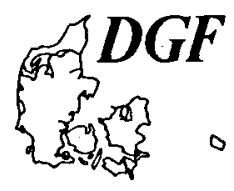

\begin{abstract}
Wang Xiaofeng \& Erdtmann, B-D.: Zonation and correlation of the earliest Ordovician graptolites from Hunjiang, Jilin Province, China. Bull. geol. Soc. Denmark, vol. 35, pp. 245-257. Copenhagen, July 1st, 1987.

On the basis of studies of the graptolite succession at the Xiaoyangqiao, Qinggouzi and Muxiantogou sections in the vicinity of Dayangcha village and near Hunjiang City in SW Jilin Province four graptolite zones can be recognized in the 'Yeli Formation': 1. Rhabdinopora parabola Zone, 2. Anisograptus Zone, 3. Psigraptus Zone and 4. Adelograptus-Clonograptus Zone. The correlation of each zone with the equivalent zone and the Cambrian-Ordovician boundary both in China and in other areas of the world are discussed.
\end{abstract}

Wang X., Yichang Inst. Geol. \& Min. Res., Chinese Acad. Geol. Sci., Yichang City, Hubei Province, People's Republic of China; B-D. Erdtmann, Geol.-Paläont. Inst. Univ. Göttingen, D-3400 Göttingen, Federal Republic of Germany, August 30st, 1985.

The Xiaoyangqiao section near Dayangcha village ca. $50 \mathrm{~km}$ E of Hunjiang, Jilin Province is considered to be of one of the best CambrianOrdovician boundary sections discovered in China in recent years. This section was first reported by Kuo et al. (1982). Chen et al. (1983, 1985 ) outlined a zonation scheme of this area when they discussed the faunal sequence across the Cambrian-Ordovician boundary in northern China. In the summer 1984 the senior author, accompanied by Mrs. Liang Zhongfa and Yan Hui, and in May 1985 also by the junior author investigated this section and the Qinggouzi and Muxiantougou sections near Hunjiang City. The authors believe that the earliest Ordovician graptolite sequence there is well represented with regard to the first occurrence of Rhabdinopora and probably documents the best Tremadoc graptolite sequence in China. These sections, therefore, are very important for study of earliest Ordovician graptolite zonation and for correlation of the Cambrian-Ordovician boundary both within China and to other areas of the world.

\section{Graptolite sequence}

The Xiaoyangqiao Cambrian-Ordovician boundary section lies near Xiaoyangqiao, north of the Dayangcha train station and the Qinggouzi sec- tion is in the south roadside of the exit of the Quinggouzi reservoir (Fig. 1). Based on the distribution of graptolites in these two and other nearby sections four graptolite zones can be recognized in the 'Yeli (Yehli) Formation' of the Hunjiang area, named as follows in descending order (Fig. 2):

\section{(4) Adelograptus-Clonograptus Zone \\ (3) Psigraptus Zone \\ (2) Anisograptus Zone \\ (1) Rhabdinopora parabola Zone}

The Hunjiang area is situated in the northern fringe of the North China Ordovician biofacies region and borders on the Tianshan-Xinan region (Wang, 1980; Lai et al., 1982), so that the uppermost Cambrian-lowermost Ordovician atrata here are not fully equivalent to those exposed in the Tangshan area, Hebei Province and in the Taizihe (Taizuho) Valley, Liaoning Province in their lithological characteristics. The Yeli Formation, used in the present area by Kuo et al. (1982) and Chen et al. $(1983,1985)$, in fact includes some equivalent strata to the Qiushugou (Chiushukou) Member of the Fengshan Formation from the Taizihe Valley, Liaoning, which was originally regarded as being of late Cambrian age (Mu, 1953, 1955; Zhao, 1983; Zhao et Chen, 1984). In advance of future revision at the litho- 


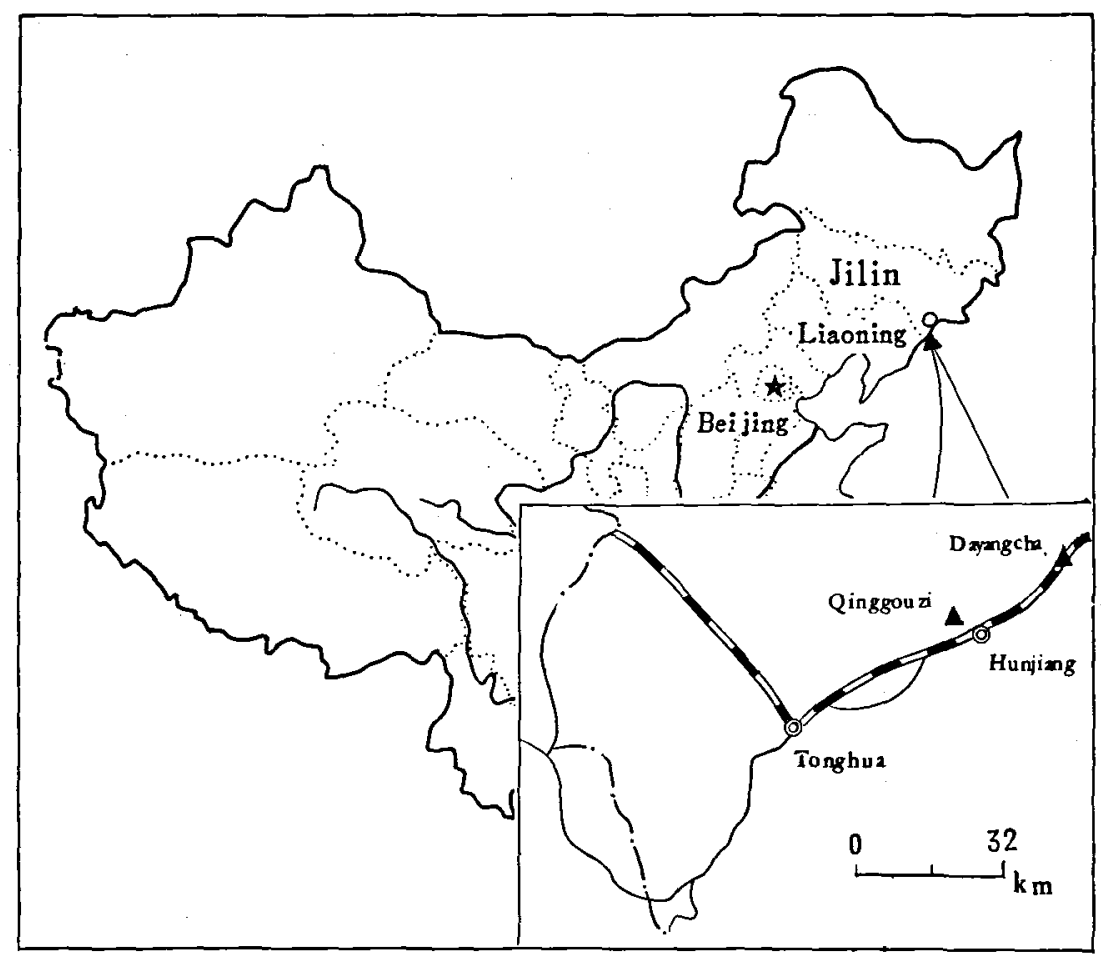

Fig. 1. Sketch map showing location of measured sections in the Hunjiang area.

stratigraphic units in the area and in order to avoid the confusion with the typical Fengshan and Yeli Formations these two names are used in present paper, in generalized sense indicated by applying single quotation marks to their names.

\section{Correlation}

\section{Rhabdinopora parabola Zone}

This zone, representing the lowermost Ordovician graptolite zone, is characterized by the appearance of Rhabdinopora parabola (Bulman) (see pl. 2, figs. 1, 3, 8-9; pl. 3, fig. 1) in association with $R$. flabelliformis s.l. (Eichwald) (see pl. 3, fig. 9), R. socialis (Salter) (see pl. 2, fig. 5) and the trilobite Richardsonella, cystoids Echinosphaerites $\mathrm{sp}$. The above mentioned graptolites are found at the base of the yellow-greenish mudstone with bands of thin-bedded limestone, $1.5 \mathrm{~m}$ thick at the base of the 'Yeli Formation', which is probably equivalent to the lower part of Bed 14 at the Dayangcha section, measured by Kuo et al. (1982) or Bed 21 (of Chen et al., 1985). The first appearance of $R$. flabelliforme represented by $R$. parabola is thought to be an important mark for determining the base of the Tremadoc (Bulman, 1954; Erdtmann, 1982). The associated R. socialis is also an indicator defining the base of the Tremadoc, though it sometimes can range up to a slightly higher level (Bulman, 1954). R. socialis of the present paper provinsionally remains in the sense of 'Dictyonema' flabelliforme sociale Salter of Bulman $(1927,1954)$, but the probability of synonym of $R$, socialis with $R$. flabelliformis can not be ruled out. This idea had already been pointed out by Salter himself (1858) and by Erdtmann (1982). Based on the graptolite assemblage the $R$. parabola Zone from the 'Yeli Formation' of the Hunjiang area is easy to correlate with the beds containing $R$. parabola and $R$. socialis near the base of the Cambrian-Ordovician boundary interval at the Naersnes section, Oslo, Norway (Bruton et al., 1982), and it also correlates with the $R$. flabelliformis Zone from Taimyr, USSR (Obut et Sobolevskaya, 1964) that includes $R$. parabola and $R$. socialis. In western Newfoundland, $R$. flabelliformis and parabola type and $R$. socialis were also reported to occur at the base of the Tremadoc at Broom Point South section (Fortey et al. 1982), but recent investigations by the junior author cast doubts upon the occurrence of 


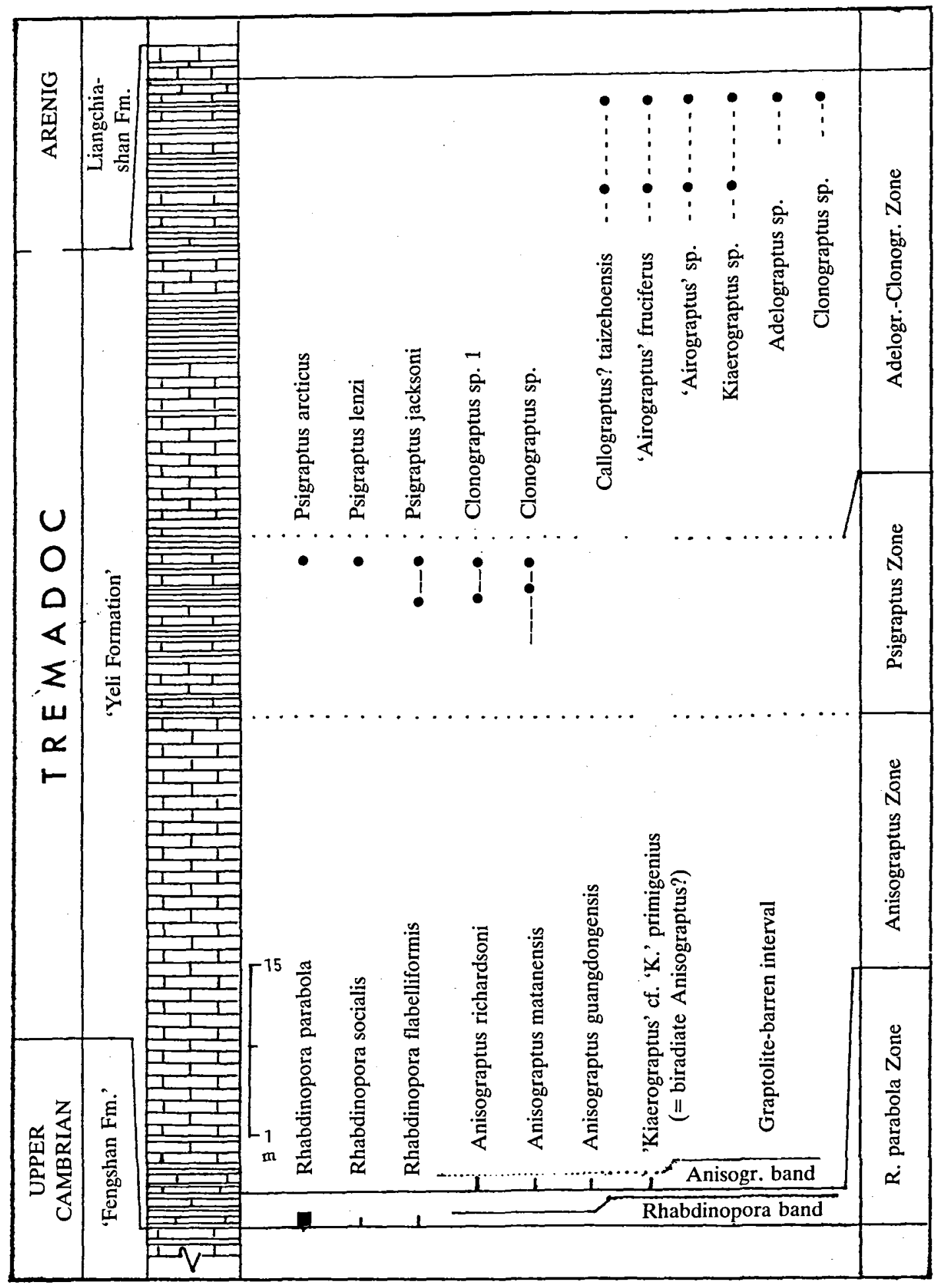

Fig. 2. Stratigraphic distribution of principal graptolites at the Xiaoyangqiao section near Dayangcha, Hunjiang, Jilin. 
the forms in that section of the Cow Head Group. Rushton (1982) proposed to define the base of the type Tremadoc at or just below, the lowest beds with $R$. ex gr. socialis (Salter) at Brynllinfawr section in North Wales. This boundary is basically coeval with that between the 'Yeli' and 'Fengshan' Formations in the present area. The definition of the Cambrian-Ordovician boundary and the correlation between different fossil assemblages relevant to this interval are subjects of international discussion (Norford, 1982). It is imperative to define the base of the Tremadoc as the Cambrian-Ordovician boundary, since this boundary is not only advantageous to an internationally precise correlation, but also coincides with one of the most important events in graptolite evolution: the appearance of the nematophorous coni-siculate anisograptoids with the virtually synchronous first occurrence of the pendent Rhabdinopora group and the horizontal Staurograptus group. At the Xiaoyangqiao and Qinggouzi sections this boundary should be drawn at or just below the base of the $R$. parabola Zone.

It was reported by Lin (in Chen et al., 1983) that the following graptolites were found in the lowermost part of the 'Yeli Formation' at the Dayangcha section: 'Dictyonema' flabelliforme Eichwald, Staurograptus dichotomous Emmons and Anisograptus mirus Lin, without appending illustrations and descriptions. The first full description and illustration of this graptolite fauna is given by Lin (in Chen et al., 1985). Researches of this section show that among the graptolites associated with Rhabdinopora parabola, $R$. socialis, and $R$. flabelliformis some forms possess some similar features to 'Staurograptus' (see pl. 2, fig. 1) and 'Anisograptus' (see pl. 2, fig. 2) but they represent juvenile growth stages of $R$. parabola with 4 'primary' stipes ( $=2$ primary and 2 pseudoprimary stipes), and Rhabdinopora with 3 'primary' stipes (=2 primary and 1 pseudo-primary stipes), respectively. The real Anisograptus appears in beds $2.5 \mathrm{~m}$ above the $R$. parabola band at the Xiaoyangqiao section near Dayangcha or in beds $4.1 \mathrm{~m}$ above the $R$. parabola band at the Quinggouzi section, where no graptolites belonging to the Rhabdinopora type are found (pl. 1, figs. 1-2), although at Muxiantougou, a parallel valley section ca. $1.5 \mathrm{~km}$ to the west, these occur $2.1 \mathrm{~m}$ below the Anisograptus beds.
Also it has been reported that Anisograptus sp. A, Staurograptus minutus Mu?, Triograptus osloensis minor Ruedemann, Aletograptus sp., Kiaerograptus spinicrispus Yu, Lin et Fang and Bryograptus jiangxiensis Yu, Liu et Fang, along with 'Dictyograptus' parabola (= Rhabdinopora parabola) were found in the base of the 'Tangpan Formation' (i.e. the upper part of the original Xiyangshan Formation) at Wuning, Jiangxi Province (Yu et al., 1982, 1985). Based on the researches of that section by senior author the above mentioned graptolites, associated with $R$. parabola, are likely to be juvenile stages of $R h a b$ dinopora except for $K$. spinicrispus, which is probably identical to or related to 'Kiaerograptus' primigenius (Bulman). The latter probably represents an imture biradiate 'morph' of the Staurograptus-Anisograptus plexus. The graptolites belonging to the Staurograptus-Anisograptus Zone occur in beds just $1.6 \mathrm{~m}$ above the $R$. parabola Zone at Wuning. If this is correct, the $R$. parabola Zone there is equivalent to the zone of the same name of the Hunjiang area, while the overlying Staurograptus-Anisograptus Zone should be correlated with the Anisograptus Zone at Hunjiang (table 1).

\section{Anisograptus Zone}

The base of this zone is provisionally drawn at the base of Anisograptus band, since a graptolite barren interval, $2.5 \mathrm{~m}$ thick, exists between the Rhabdinopora and Anisograptus bands. At the Xiaoyangqiao section, the Anisograptus band consists of yellow-greenish shale or grey thin bedded limestone intercalated with yellow-greenish or purplish shale, above the $R$. parabola Zone (pl. 1, fig. 1) and extends for ca. $1 \mathrm{~m}$. The Anisograptus band is likely to belong to the upper part of Bed 14 and lower part of Bed 15 of the Xiaoyangqiao (Dayangcha) section as measured by Kuo et al. (1982) or Bed 23 and 24 of Chen et al. (1985). It is followed by approximately $4 \mathrm{~m}$ of graptolite-barren limestone before the appearance of elements showing the Psigraptus Zone. At the Qinggouzi section, the graptolites of the Anisograptus band is similar to that of the Xiaoyangqiao section, but the thickness between this band and the underlying Rhabdinopora band increases to $4.1 \mathrm{~m}$. Common graptolites of the Anisograptus band are Anisograptus richardsoni Bulman, A. matanensis Ruedemann, A. guang- 
Table 1. Correlation of the early Ordovician Hunjiangian graptolite zones of Hunjiang, Jilin with other places both in China and elsewhere.

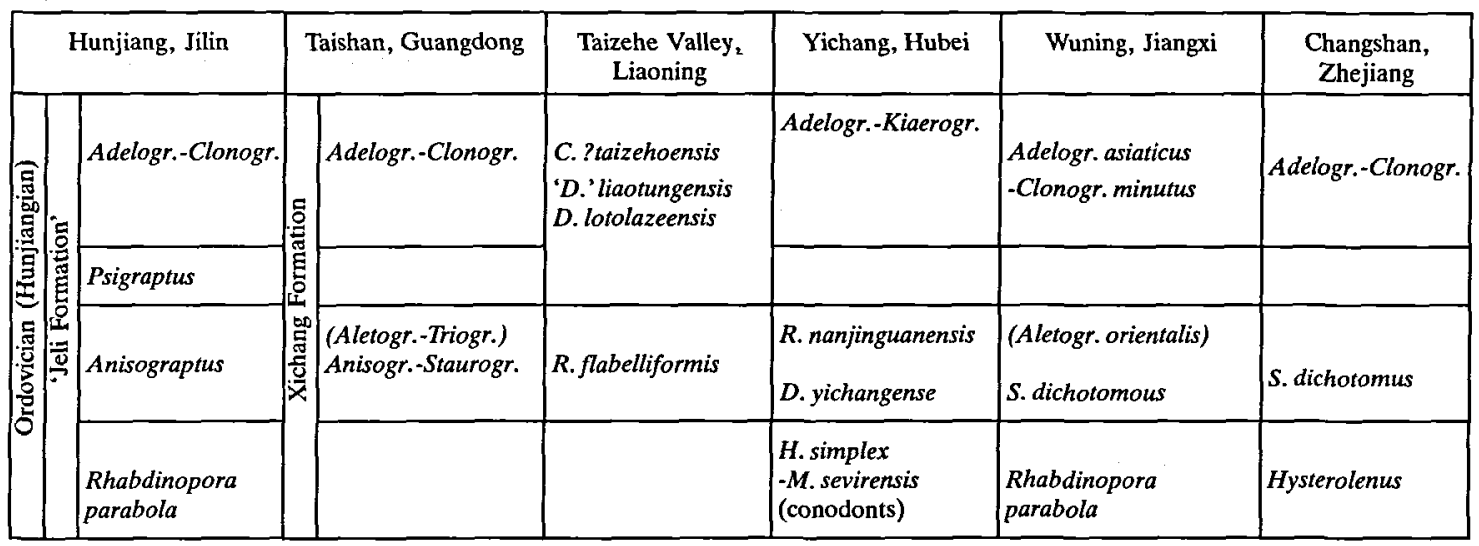

\begin{tabular}{|c|c|c|c|c|c|c|c|}
\hline \multicolumn{2}{|c|}{ Hunjiang, Jilin } & Oslo, Norway & Victoria, Australia & Yukon, Canada & $\begin{array}{c}\text { Newfoundland, } \\
\text { Canada }\end{array}$ & \multicolumn{2}{|c|}{$\begin{array}{c}\text { G. Britain } \\
\text { (N. Wales, Shropshire) }\end{array}$} \\
\hline \multirow{5}{*}{ 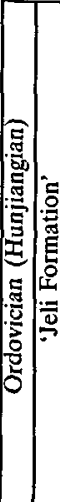 } & & Ceratopyge Lst. & A. victoriae- & & Clonogr.flexilis & $?$ & \\
\hline & Adelogr. -Clonogr. & $\begin{array}{l}\text { K. kiaeri, B. kjerolfi } \\
(3 \mathrm{a \beta}-3 \mathrm{a}) \text { ) }\end{array}$ & 'D.' macgillivrayi & $\begin{array}{l}\text { K. antiquus } \\
\text { (with Psigraptus } \\
\text { near base) }\end{array}$ & -Adelograptus & \multirow{4}{*}{ 总 } & $\begin{array}{l}\text { Angelina sedgwickii } \\
\text { Shumadia pusilla }\end{array}$ \\
\hline & Psigraptus & $3 a$ & $\begin{array}{l}\text { Psigraptus } \\
\text {-Clonograptus }\end{array}$ & C.aureus & & & C.tenellus \\
\hline & Anisograptus & $\begin{array}{l}\text { Anisogr. }(2 \mathrm{e} \delta) \\
\text { R. flab. }(2 \mathrm{e} \beta-\mathrm{r})\end{array}$ & $\begin{array}{l}\text { 'D.'scitulum } \\
\text {-Anisograptus }\end{array}$ & $\begin{array}{l}\text { A. richardsoni } \\
\text { S. tenuis }\end{array}$ & $\begin{array}{l}\text { A. richardsoni } \\
\text { Psigr.? canadensis } \\
\text { Radiograptus }\end{array}$ & & \\
\hline & R. parabola & $\begin{array}{l}\text { R. parabola-socialis } \\
\text { R. praeparabola }\end{array}$ & & & $\begin{array}{l}\text { R. cf. parabola? } \\
\text { Staurograptus? } \\
\text { R. cf. praeparabola }\end{array}$ & & \\
\hline
\end{tabular}

dongensis Wang, Liu et Zhou, and rarer forms include 'Kiaerograptus' primigenius (Bulman) and ?Staurograptus sp. In Canada, Anisograptus richardsoni has been reported from the Anisograptus Zone above the $R$. flabelliformis s.l. Zone (Erdtmann, 1971) and regarded as an index fossil of the Anisograptus richardsoni Zone in the Yukon (Jackson, 1974, 1975). The latter zone overlies the Staurograptus tenuis Zone. The graptolite assemblage shows that the Anisograptus Zone of the present area may be correlated with the same name zone of Newfoundland and the Staurograptus tenuis and Anisograptus richardsoni Zone of Yukon. Anisograptus richardsoni with Staurograptus, Radiograptus, 'Triograptus' and Rhabdinopora, excluding $R$. socialis, were also found in the Matane Shale, Quebec, Canada (Bulman, 1950). The beds bearing these graptolites are roughly equivalent to the Anisograptus Zone of the present area in age and also could correspond to the beds containing Anisograptus above the $R$. socialis Zone in Argentina (Turner, 1960) and with the Unites 2-7, yielding Anisograptus richardsoni, Rhabdinopora flabelliformis s.l., 'Triograptus' canadensis and Aletograptus from Taimyr, USSR. According to Cooper and Stewart (1979), in Australia the 'Dictyonema' scitulum Anisograptus Zone is characterized by the appearance of ' $D$.' scitulum, Anisograptus compactus and $A$. delicatulus. $A$. compactus is closely related to $A$. richardsoni (Erdtmann and Botsford, in prep.), while $A$. delicatulus probably is identical with $A$. guangdongensis Wang, Liu et Zhou, but the latter was published a little earlier than the former. The ' $D$.' scitulum-Anisograptus Zone is correlative in age of the Anisograptus Zone of 
the present area. The Dictyonema Shale $(2 \mathrm{e} \beta-$ $2 e \delta$ Subzone) at the Töyen and Hammersberg section in Oslo, Norway probably also correlates with the Anisograptus Zone from Hunjiang, or its top limit is is slightly lower.

Since Mu (1974) divided the Xinchang Formation, Taishan, Guangdong Province into three graptolite zones, they have been widely quoted in Chinese literature ( $\mathrm{Mu}$ et al., 1979, 1980; Yu et al., 1982, 1985). These authors considered that the lowest Anisograptus-Staurograptus Zone represents the lowest Tremadoc graptolite zone. There is, however, no evidence to show that the base of the Anisograptus-Staurograptus Zone at the Xinchang section coincides with that of the Tremadoc (Xu et al., 1983; Chen et Lenz, 1983) because no fossil has been found below this zone as yet (Wang et al., 1979). The earliest Ordovician graptolite sequence from the Hunjiang area shows that the Anisograptus-Staurograptus Zone (x1) there can only be compared with the Anisograptus Zone of the present area. $R$. parabola Zone graptolites are absent in Xinchang owing to an inhospitable ecostratigraphical environment. According to $\mathrm{Lu}$ et al. (1983) an interval with trilobites of the Hysterolenus Zone, at least $25 \mathrm{~m}$ thick, exists between the $S$. dichotomus Zone and the Cambrian-Ordovician boundary in the Jiangshan-Changshan area, Zhejiang Province. On the other hand, it is apparent that the base of the $S$. dichotomus Zone there can not be correlated with the base of the Tremadoc as marked by the first appearance of $R$. flabelliformis of socialis or parabola type. The Cambrian-Ordovician boundary in the Jiangshan-Changshon area should be defined at the base of the Hysterolenus Zone, but not at the base of the $S$. dichotomus Zone (Wang, 1980; Lai et al., 1983; Lu et al., 1983). In the Taojiang area, Hunan Province, the $R$. flabelliformisStaurograptus Zone at the base of the Baishuxi Formation is characterized by yielding numerous $R$. socialis (Jin et Wang, 1977). Associated with $R$. socialis are Rhabdinopora taojiangensis and 'Staurograptus diffissus'. The former is a small slender form virtually without dissepiments, which may, if a synonym could be proven, be identical with $R$. praeparabola Erdtmann (1982) and a senior synonym of the latter. 'Staurograptus diffissus' was considered to be identical with Staurograptus minutus $\mathrm{Mu}(\mathrm{Mu}, 1980)$. Since the specimens of this form are quite rare and very small, the present authors suspect that they represent juvenile growth stages of Rhabdinopora. The Analysis of the graptolite fauna from the Upper Qiushugou Member of the Fenshan Formation, Benxi, Liaoning Province as reported by Zhao (1983) and by Zhao and Chen (1984), suggest that the $R$. flabelliformis-Staurograptus Zone is likely to be a correlative of the middle Dictyonema Shale of Norway and slightly younger than the $R$. parabola Zone. The associated 'Staurograptus' (Zhao, 1983, pl. 4, figs. $1-4,6-8$ ) is possibly not a true Staurograptus, but belongs either to Anisograptus or represent young astogenetic growth stages of Rhabdinopora.

\section{Psigraptus Zone}

This zone is found in the grey and dark grey shale with beds of thin bedded limestone in the middle part of the 'Yeli Formation' at Erdaopuzi village near Xiaoyangqiao, $4 \mathrm{~km}$ E of Dayangcha (see also Zhao \& Zhang, 1985). Its position in the sequence is about $16 \mathrm{~m}$ above the underlying $A n i-$ sograptus Zone. This zone is marked by yielding Psigraptus arcticus Jackson, $P$. lenzi Jackson and $P$. jacksoni Rickards et Stait as well as Clonograptus sp. 1 and $C$. sp. with small size and slender stipes (see pl. 2, figs. 6-7) which are similar to those described by Cooper and Stewart (1979). The first mentioned two species of Psigraptus occuring in the uppermost part of this zone were originally discovered by Zhao and Zhang (1986). In slightly lower interval of 1-3 m thick numerous $P$. jacksoni associated with $\mathrm{Clo}$ nograptus were obtained by Zhao \& Zhang (1985), and by the present authors. Psigraptus lenzi and $P$. arcticus were first reported from beds probably belonging to the lowest Kiaerograptus

Fig. 1. The Cambrian-Ordovician boundary at the Xiaoyangqiao section near Dayangcha village, Hunjiang, R: showing the locality of the $R$. parabola band occurring in the base of the $R$. parabola Zone; A; the locality of the Anisograptus band at the base of the-Anisograptus Zone. The Cambrian-Ordovician boundary is drawn at or just below the base of the $R$. parabola band.

Fig. 2. The Qinggouzi Cambrian-Ordovician boundary section. R: the locality of the $R$. parabola band. The hammer indicates the boundary between the Ordovician and Cambrian systems. 

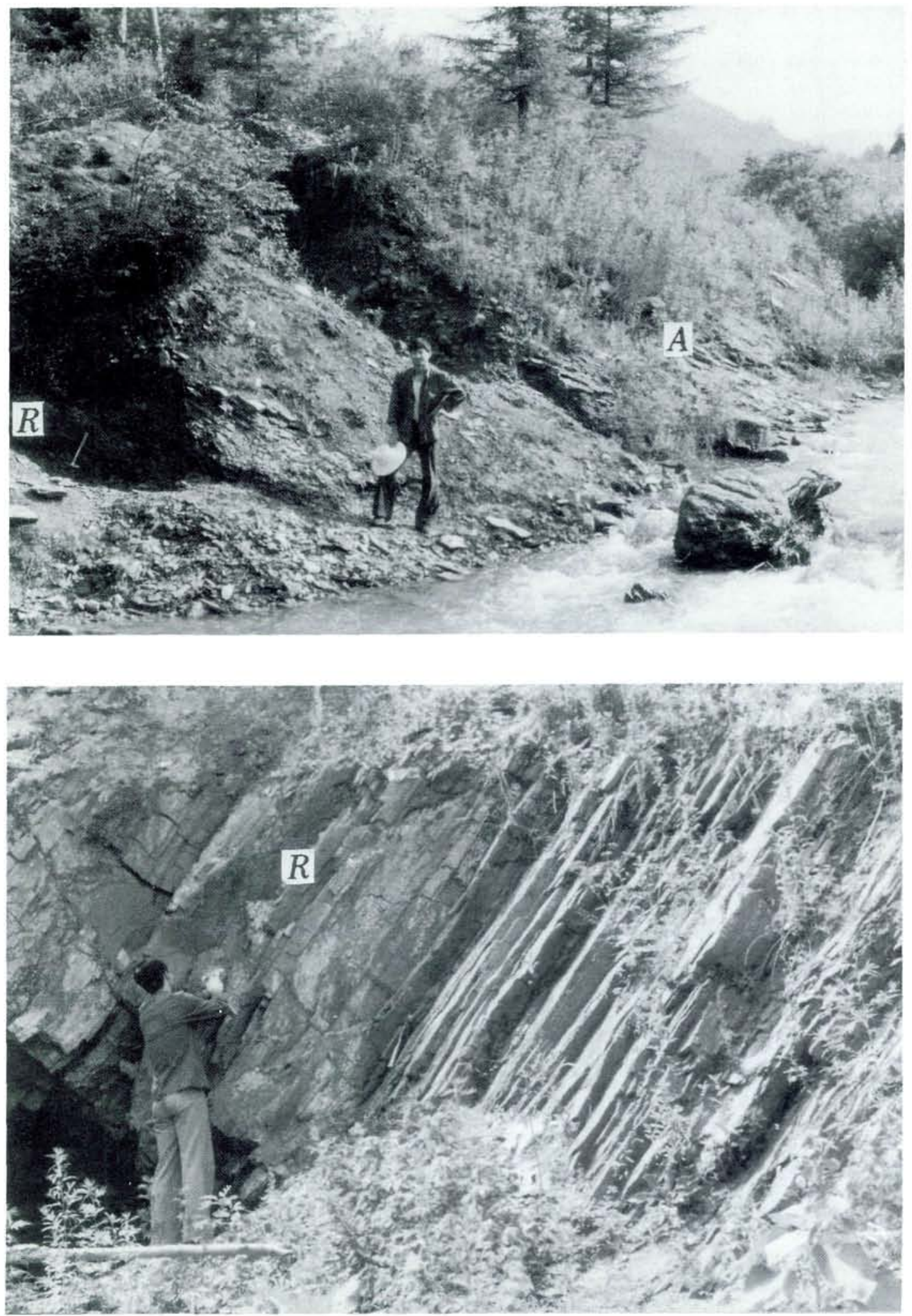
antiquus Zone (Jackson, 1967, 1974, 1975). The former species is also known from a thin shale seam between the $\mathrm{La} 1$ and $\mathrm{La} 2$ intervals in Victoria, Australia, along with small and slender Clonograptus. The Psigraptus-Clonograptus Zone was proposed by Cooper and Stuart (1979) for this interval. $P$. jacksoni is known only from the Tremadoc of the Florentine Valley in Tasmania, Australia (Rickards and Stait, 1984). The level of which this species is occuring is likely to be equivalent to that of $P$. lenzi or a little lower. The discovery of Psigraptus in Hunjiang is important for the study of anisograptoid evolution, for worldwide stratigraphical correlation and for palaeoenvironmental reasons. Based on the graptolite assemblage the Psigraptus Zone of present area may be correlated with the Psigraptus-Clonograptus Zone of Lancefield in Victoria, Australia and with the lowest Kiaerograptus antiquus Zone in the Yukon, Canada, or it may be slightly older. As to the taxonomy of Psigraptus, we are inclined to agree with Rickards' and Stait's (1984) idea, that the genus Yukonograptus (with Psigraptus lenzi as type species) and the new family Psigraptidae erected by Lin Yao-kun (1981) should not be supported. It needs to be further pointed out that the recently reported four new genera (Muenzhigraptus, Diphygraptus, Hunjiangograptus and Holopsigraptus) and the eight new species from Hunjiang area by Zhao and Zhang (1985) appears to be identical with Psigraptus jacksoni Rickards et Strait. The new family they suggested Muenzhigraptidae, likewise can not be supported.

The upper two zones of Mu's division (1974) of the Xinchang Formation, Taishan, Guangdong Province are the Aletograptus- 'Triograptus' Zone and the Adelograptus-Clonograptus Zone. In the 'Tangpai Formation' at Wuning, Jiangxi Province, Aletograptus and 'Triograptus' are also present in the underlying Staurograptus dichotomus Zone (Yu et al. 1982). Chen and Lenz (1984) pointed out that the 'Triograptus' at Wuning probably is a juvenile rhabdosome of Anisograptus.

\section{Adelograptus-Clonograptus Zone}

This zone, representing the uppermost graptolite zone of the 'Yeli Formation', was first found near the Dayangcha Village by Lin (in Chen et al, 1983). The following species are reported: $\mathrm{Clo}$ nograptus sinensis $(\mathrm{Mu})$, C. uniformis $(\mathrm{Mu})$, Adelograptus papillinaceus $\mathrm{Lin}$, A. asiaticus $\mathrm{Mu}$, A. victoriae (T. S. Hall) and Kiaerograptus heng-

(All specimens shown on plate 2 occur in the Xjaoyangiao section except for Figs. 3,5.)

Fig. 1. Rhabdinopora parabola (Bulman)

$\times 9$, juvenile rhabdosome with pseudo-quadriradiate (two primary stipes and two pseudo-primary stipes) proximal development, which is similar to Staurograptus in shape preservation. HL-2, $R$. parabola Zone of the 'Yeli Formation'.

Fig. 2. Rhabdinopora sp.

Juvenile specimen with pseudo-triradiate (two primary stipes and one pseudo-primary stipe) proximal development, $\times 9$, HL-2, horizon same above.

Fig. 3. Rhabdinopora parabola (Bulman)

An young rhabdosome, showing the sicula and fibrous nematic sheafs, $\times 3, \mathrm{Hj} 1$, the $R$. parabola Zone at the base of the 'Yeli Formation' of the Qinggouzi section, Hunjiang.

Fig. 4. Kiaerograptus? primigenius (Bulman) (= probably a bi-radiate morph of Anisdgraptus) $\times 4.5$, HL 3, Anisograptus Zone of the 'Yeli Formation'.

Fig. 5. Rhabdinopora socialis (Salter)

$\times 3$, Hj 1, locality and horizon same as Fig. 3.

Fig. 6-7. Clonograptus sp. 1 Cooper \& Stewart

All $\times 3$, HX 1, Psigraptus Zone of the of the 'Yeli Formation'.

Figs. 8-9. Rhabdinopora parabola (Bulman)

8. A juvenile specimen with pseudo-quadriradiate development and one dissepiment, which is similar to Radiograptus in shape preservation, $\times 4.5, R$. parabola Zone of the 'Yeli Formation'; 9 . A mature specimen with a juvenile specimen, $\times 3$, same horizon.

Fig. 10. Psigraptus jacksoni Rickards \& Stait

This specimen shows the pseudo-triradiate development formed by two reclined primary stipes and one reclined pseudo-primary stipe and secondary branches up to 3 rd order, in the proximal part of the rhabdosome, the autothecae are curved, aperturally isolated, less to distally. $\times 10, \mathrm{HX} 1$, Psigraptus Zone of the 'Yeli Formation', Erdoupuzi near Xiaoyangqiao. 
Plate 2
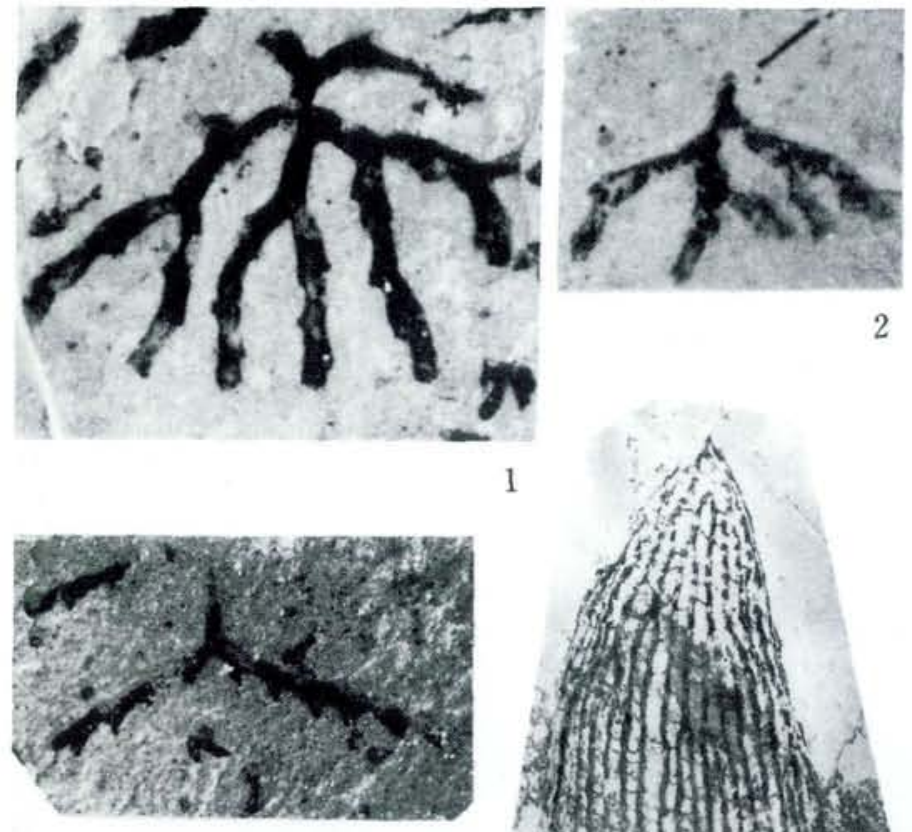

4
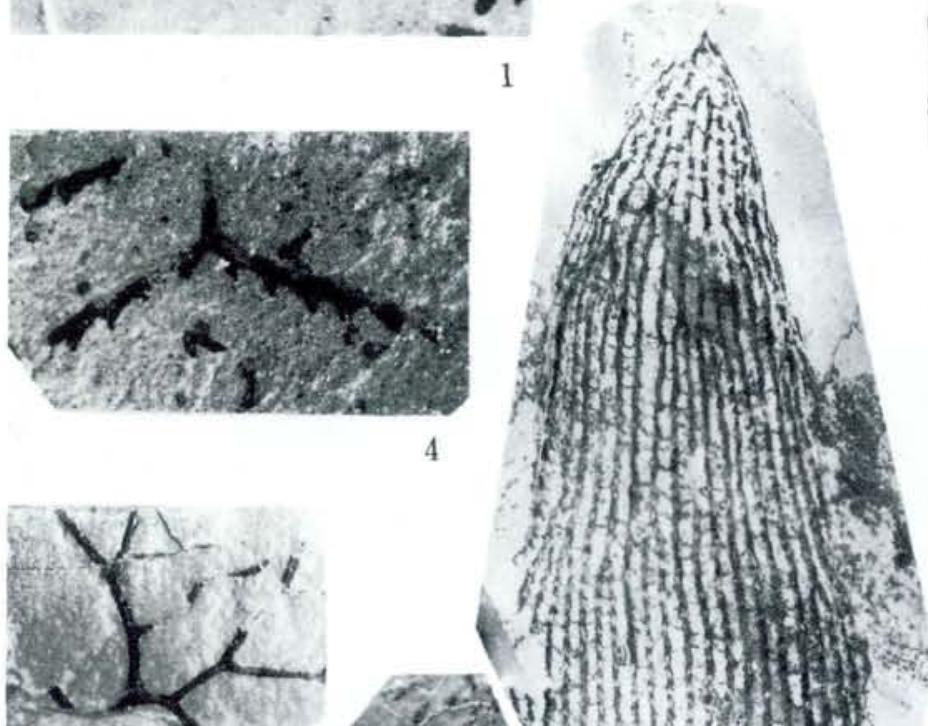
bian

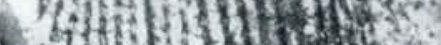
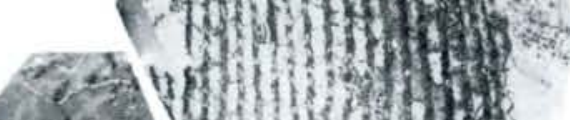

7

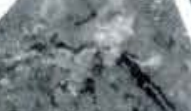

4) m 12
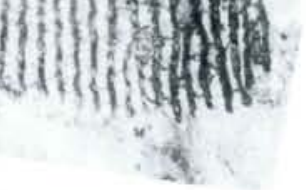

5
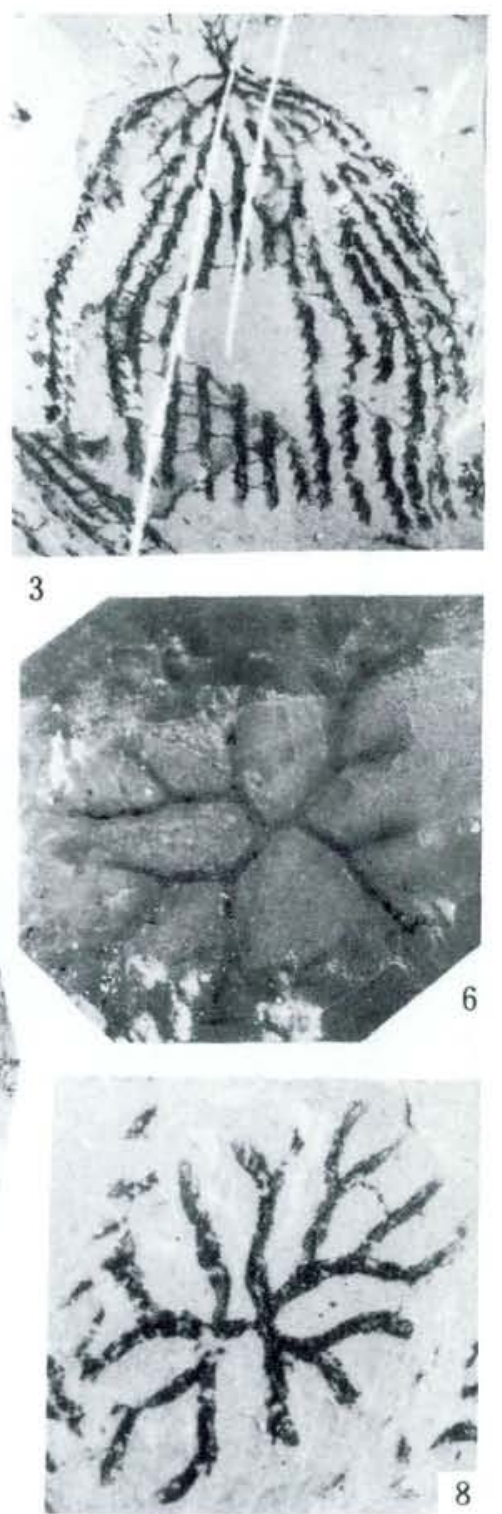

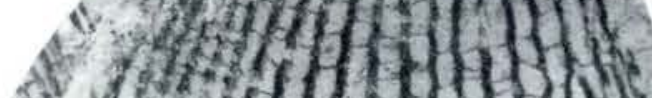
5)

$3 x$ and

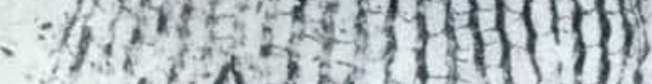

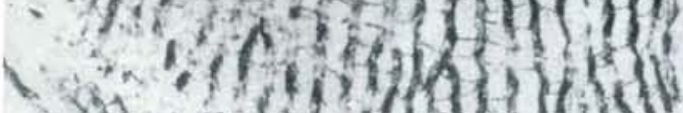
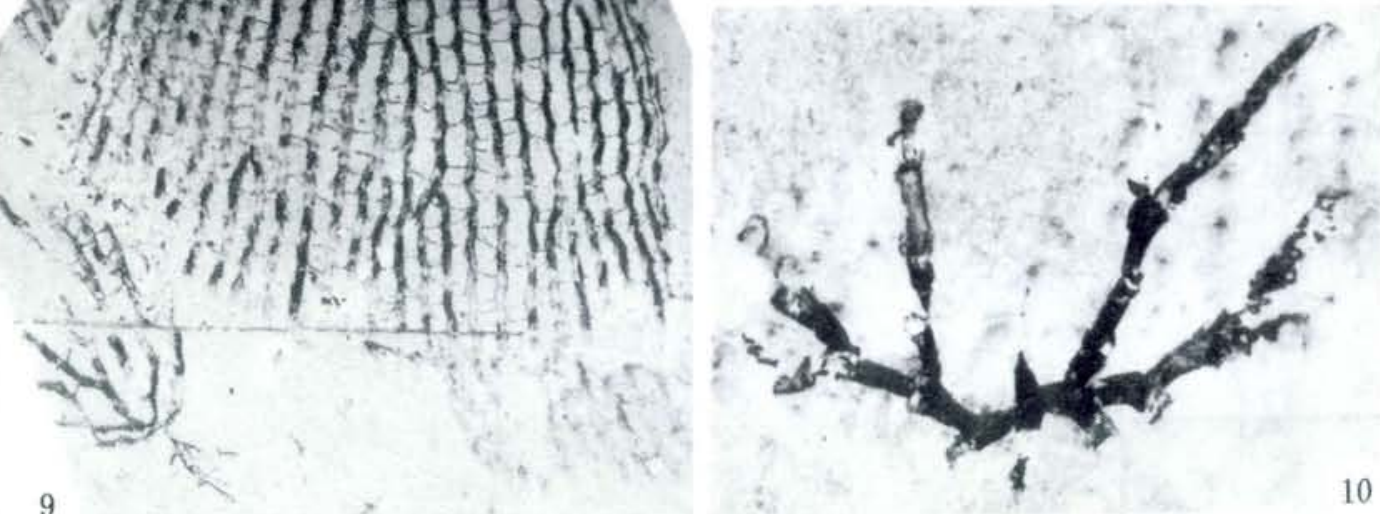
shanensis Lin. At the Xiaoyangqiao section the following graptolites have been found in the yellow-greenish and grey-greenish shale intercalated with thin bedded limestone, about $15 \mathrm{~m}$ thick in the uppermost part of the 'Yeli Formation': Callograptus ? taizehoensis $\mathrm{Mu}$ (pl. 3, fig. 8), 'Airograptus' sp. A, 'A.' furciferus (Ruedemann) (pl. 3, figs. 3-4), Dictyonema sp. and Adelograptus? sp. The boundary between the 'Yeli' and Liangchiashan Formations is not exposed due to cover. In the same level Kiaerograptus and Adelograp. tus were also found by Zhao and Zhang (1985) and by the junior author. This shows that the $C$.? taizehoensis Zone of the present area, which we proposed in the abstract of this paper submitted to the Graptolite conference of Copenhagen in 1985 , has to be discarded. Based on these graptolites the Adelograptus-Clonograptus Zone of the present area is roughly equivalent to the same name zone of the Xinchang Formation, South China, to the Adelograptus victoriae-'Dictyonema' magillivrayi (La 2) Zone of Victoria, Australia and the upper Kiaerograptus antiquus Zone of Yukon, Canada (table 1).

A major hiatus, documented by an angular unconformity or at least an erosional disconformity exists between the 'type' - Tremadoc and Arenig in Great Britain. The graptolites being equivalent to the Adelograptus-Clonograptus Zone of the present area or to the $\mathrm{La} 2$ and La 3 interval of Australia are absent there. The chronostratigraphic gap neccessitates a redefinition of the Tremadoc and Arenig Series or the establishment of a new series to fill this major gap. The Hun- neherg Stage of Tjernvik $(1956,1980)$ would best satisfy this requirement but its inclusion with either the Tremadoc or the Arenig Series, or the insertion of Hunneberg as a new series would have to be defined and decided by the IUGS Subcommission on Ordovician Stratigraphy.

\section{Conclusions}

On the basis of the studies of graptolite succession from the Xiaoyangqiao near Dayangcha and Qinggouzi sections across the Cambrian-Ordovician boundary four Hunjiangian (or Tremadoc) graptolite zones can be recognized in the 'Yeli Formation' of Hunjiang area, Jilin Province: 1. Rhabdinopora parabola Zone, 2. Anisograptus Zone, 3. Psigraptus Zone and 4. AdelograptusClonograptus Zone. At present they comprise the best earliest Ordovician graptolite zonal sequence in China. In view of the graptolite assemblage of each zone the following ideas are proposed in the present paper:

1. The graptolite sequence of the Xinchang Formation, Guangdong Province, which is widely used in China and correlated with the Tremadoc Series in age, actually is not complete nor fully representative. The Anisograptus-Staurograptus Zone at the base of the Xinchang Formation is only equivalent to the Anisograptus Zone of the present area. Graptolites equivalent to the earliest Ordovician $R$. parabola Zone are absent in Xinchang, Guangdong. If the base of the Tremadoc Series were to be accepted for the base of the

(All specimens shown in plate 3 occur in the Xiaoyanggiao section near Dayangcha).

Fig. 1. Rhabdinopora parabola (Bulman)

A specimen with pseudo-quadriradiate development, $\times 4.5$, HL $2, R$. parabola Zone at the base of the 'Yeli Formation'.

Fig. 2,7. Anisograptus matanensis Ruedemann

All $\times 4.5$, HL 3, Anisograptus Zone at the lower part of the 'Yeli Formation'.

Fig. 3,4. 'Airograptus' furciferus (Ruedemann)

3. $\times 3,4 . \times 9$, Adelograptus-Clonograptus Zone of the 'Yeli Formation'.

Fig. 5. Anisograptus guangdongensis Wang, Liu et Zhou

Probably a juvenile specimen, $\times 4.5$, HL 3 , same horizon as Figs. 2,7.

Fig. 6. Anisograptus richardsoni (Bulman)

$\times 3$, HL 3, same horizon as Figs. 2,7.

Fig. 8. Callograptus ? taizehoensis $\mathrm{Mu}$

$\times 4.5$, HD, same horizon as Figs. 3,4.

Fig. 9. Rhabdinopora flabelliformis (Eichwald)

$\times 3$, HL 2, same horizon as Fig. 1 . 

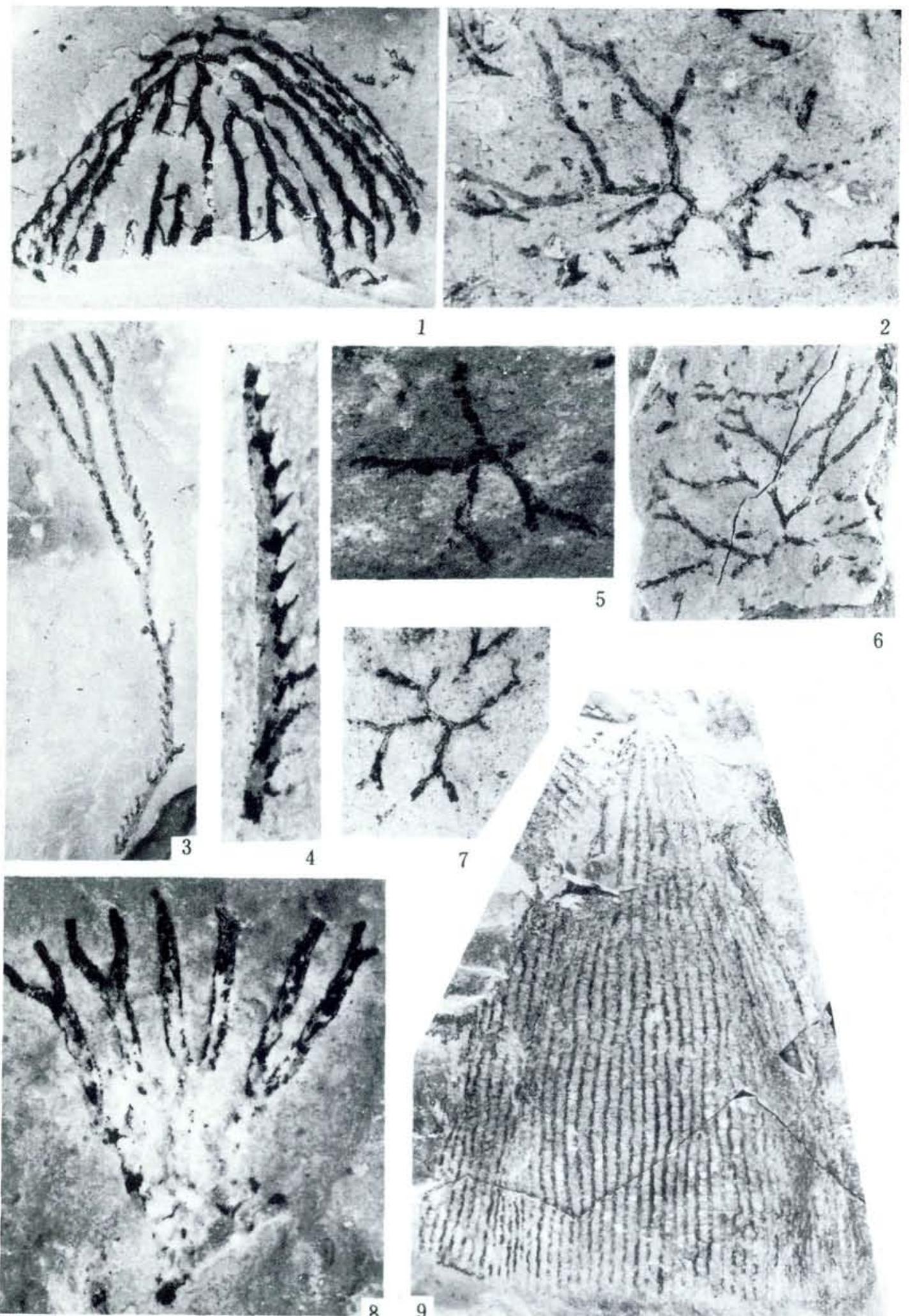

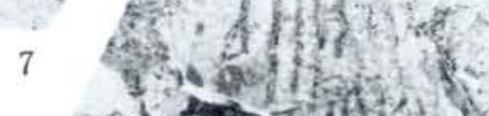

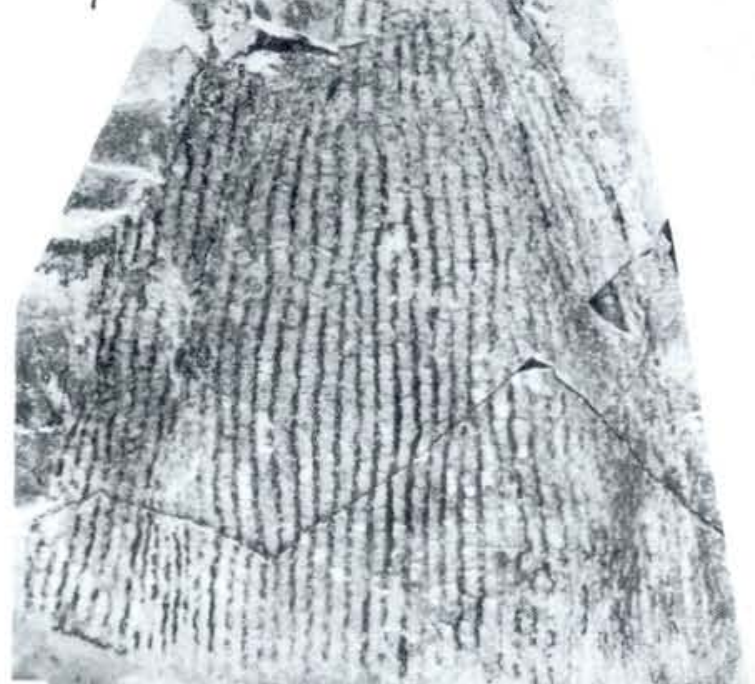


Ordovician System, the base of the $R$. parabola Zone in the lowest 'Yeli Formation' of the Hunjiang area would coincide with it or very close to this horizon. Due to its incompleteness the Xinchangian Stage, in its chronostratigraphical sense, must be discarded and the 'Hunjiangian' Stage is proposed here in its place.

2. Recognition of a Triograptus-Aletograptus Zone within the Xinchang Formation is not supported. Data from the 'Tangpan Formation', Wuning, Jiangxi Province (Yu et al., 1982, 1984) indicate that 'Triograptus' and Aletograptus are present in the Staurograptus dichotomus Zone. 'Triograptus' probably represents merely a juvenile growth stage of Anisograptus.

3. The appearance of psigraptid graptolites characterized by proximally isolated the thecae and strongly reclined stipes is thought to represent a significant event for anisograptoid evolution. The Psigraptus Zone is easily correlated with the Psigraptus-Clonograptus Zone of Victoria, Australia. It probably is early Late Tremadoc age.

4. The Adelograptus-Clonograptus Zone is considered as the uppermost graptolite zone of the 'Yeli Formation' in the present area, being equivalent to the same name zone of the Xinchang Formation and to the La 2 Zone of Australia.

Acknowledgements. We are very grateful to Drs. B. S. Norford and R. A. Cooper for critically reading the manuscript. We also wish to give our sincere thanks to Mrs. Liang Zhongfa and Yan Hui for their warm help in field work.

\section{Dansk sammendrag}

Efter studier af graptolit successionerne i Xiaoyangqiao, Qinggouzi og Muxiantogou profilerne $\mathrm{i}$ narheden af landsbyen Dayangcha og nær byen Hunjiang i den sydvestlige Jilin Provins kan fire graptolitzoner udskilles i 'Yeli Formationen': Rhabdinopora parapola Zonen, Anisograptus Zonen, Psigraptus Zonen og Adelograptus-Clonograptus Zonen.

Korrelationen af hver zone med tilsvarende zoner $i$ andre områder af verden diskuteres $i$ afhandlingen.

\section{Reference}

Bruton. D. L.. Erdtmann, B.-D. \& Koch, L. 1982: The Naersnes section, Oslo Region, Norway - a candidate for the Cambrian-Ordovician boundary stratotype at the base of the Tremadoc Series. In Dean. W. T. \& Basset, M. G, (eds): The Cambrian-Ordovician Boundary, Univ. of Wales Press, 61-69.

Bulman. O. M. B. 1927: A monography of British dendroid graptolites. pt. 1, Palaeontogr. Soc. Monogr., 1-28.
Bulman, O.M. B. 1950: Graptolites from the Dictyonema Shale of Quebec, Q.J. geol. Soc. London, 186, 63-69.

Bulman, O. M. B. 1954: The graptolite fauna of the Dictyonema Shale of the Oslo Region, Norsk Geologisk Tids., 33, $1-40$.

Chen Jun-yuan, Teichert, C., Zhou Zhi-yi, Lin Yao-kun, Wang Zhi-hao \& Xu Jun tao 1983: Faunal sequence across the Cambrian-Ordovician boundary in northern China and its international correlation, Geol. et Palaeont., 17, 1-15.

Chen Jun-yuan, Qian Yi-yuan, Lin Yao-kun, Zhang Jun-ming, Wang Zhi-hao, Yin Leiming \& Bernd-D. Erdtmann, 1985: Study on Cambrian-Ordovician boundary strata and its biota in Dayangcha, Hunjiang, Jilin, China. China Prosp. Pub. House, 1-8.

Chen Xu \& Lenz, A. C. 1984: Ordovician graptolite zonation and correlation with specific reference to the Pacific faunal realm, N. Jb. Geol. Paläont., 4, 212-222.

Cooper, R. A. \& Stewart, I. R. 1979: The Tremadoc graptolite sequence of Lancefield Victoria, Palaeont. 22(4), 767-797.

Erdtmann, B.-D. 1971: Ordovician graptolite zones of western Newfoundland in relation to paleogeography of the North Atlantic, Bull. Geol. Soc. Am., 82, 1509-28.

Erdtmann, B.-D. 1982: A reorganization and proposed phylogenetic classification of planktic Tremadoc (early Ordovician) dendroid graptolites, Norsk Geologisk Tids., 62, 121-144.

Fortey, R. A., Landing, E. \& Skevington, D. 1982: Cambrian/ Ordovician boundary section in the Cow Head Group, western Newfoundland, In Dean W. T. \& Bassett, M. G. (eds): The Cambrian-Ordovician Boundary, Univ. of Wales Press, 95-129.

Jackson, D. E. 1967, Psigraptus, a new genus from the Tremadocian of Yukon, Canada, Geol. Mag., 104, 311-315.

Jackson, D. E. 1974: Tremadoc graptolites from Yukon Territory, Canada, In Rickards, R. B., Jackson, D. E. \& Hughes, C.P. (eds): Graptolite studies in honour of O. M. B. Buiman, Spec. Pap. Palaeont., 13, 35-38.

Jackson, D. E. 1975: New Data on Tremadoc graptolites from Yukon, Canada, Palaeont. 18(4), 883-887.

Jin Yuqing \& Wang Xiaofeng 1979: The discovery of graptolites in the Baishuixi Formation of the early Ordovician in central Hunan and the multiramous graptolites in the Qiaotinzi Formation, Prof. Pap. Stratigr. Palaeont., Beijing, 3, 74-85 (in Chinese).

Kuo Hung-chun, Duan Ji-ye \& An Su-lan 1982: CambrianOrdovician Boundary in the North China platform with descriptiont of trilobites. Paper for the Fourth Inter. Sym. on Ordovician System, 1982, Changchun Coll. \& Geol. Press, 1-31.

Lai Cai-gen et al. 1982: The Ordovician System in China. Stratigr. of China, 5, 1-297 (in Chinese), Geol. Pub. House of Peking, China.

Lu Yan-hao. Lin Huan-ling, Han Nai-ren, Li Luo-zhao and Ju Tian-yin 1983: Cambrian-Ordovician boundary of Jiangshan-Changshan area. In Papers for the Symposium on the Cambrian-Ordovician and Ordovician-Silurian Boundaries, Nanjing, China, Nanjing Inst. Geol. \& Palaeont. (eds). 1-5.

Mu A.T. 1953: A preliminary study on the graptolites in the Taitzeho Valley, Liaotung, Acta Pal. Sinica, 1(1), 23-35.

Mu A T. 1955: The new materials of the dendroid graptolites of China, Palaeontologia Sinica, N.S.B. 1-62.

Mu A. T. 1974: Evolution, classification and distribution of graptoloid and graptodentroid, Scientia Sinica, 17, 227238.

Mu Enzhi (Mu, A. T.). Ge Meiyu, Chen Xu, Ni Yunan \& Lin Yaokun 1979: Lower Ordovician Graptolites of southwest China, Palaeont. Sinica, W.N. 156, S.B.N. 13, 1-192.

Mu En-zhi et al. 1980: Ordovician Graptolite Sequence and Biogeographic Regions in China. Scient. Pap. on Geol. for In- 
ter. Exchange, Prepared for the 26th Inter. Geol. Congr., 4, Stratigr. \& Palaeont., 35-42, Pub House of Geol. Beijing, China.

Norford, B. S. 1982: The International (IUGS) Working Group on the Cambrian-Ordovician Boundary, In Dean, W. T. \& Bassett, M.G. (eds): The Cambrian-Ordovician Boundary, Univ. of Wales Press, 7-8.

Obut, A. M. \& Sobolevskaya, R. F. 1964: Ordovician graptolites of Taimyr, Sibirsk otdel. Akad. Sci. USSR, Inst. Geol. Geophys. Novosibirsk, 1-78.

Rickards, R. B. \& Stait, B. A. 1984, Psigraptus, its classification, evolution and zooid, Alcheringa 8, 101-111.

Rushton, A. W. 1982: The biostratigraphy and correlation of the Merioneth-Tremadoc Series boundary in North Wales, In Dean W. T. \& Bassett, M. G. (eds): The CambrianOrdovician Boundary, Univ. of Wales Press, 41-59.

Salter, J. W. 1858: On Graptopora, a New Genus of Polyzoa, allied to the Graptolites, Proc. Amer. Assoc. Sci., for $1857,11,63-66$.

Tjernvik, T.E. 1956: On the Early Ordovician of Sweden, Stratigraphy and Fauna, Bull. Geol. Inst. Uppsala, 36, 107-284, Uppsala.

Tjernvik, T. E. \& Johansson, J. V. 1980: Description of the upper portion of the the drill-core from Finngrundet in the South Bothnian Bay, Bull. Geol. Inst. Univ. Uppsala, N.S., 8, 173-204, Uppsala.

Turner, J. C. M. 1960: Faunas Graptoliticas de Americal Del Sur., Rev. Assoc. Geol. Argentina, 14, 5-177, Buenos Aires.

Wang Xiaofeng, Liu Yiren and Zhou Guoqiang 1979: Graptolites from the Early Ordovician Xinchang Formation in Taishan of Guangdong, Acta Palaont. Sinica, 18(5), 493 504.
Wang Xiaofeng 1980: The Ordovician system in China, Acta Geol. Sinica, 54(1), 1-8, 54(2), 85-95.

Xu Jie (Hsü Chieh), Huang Zhigao \& Wang Xiaofeng 1983: On Some Important Problems of Ordovician Graptolite Faunas in China, In: Selected Works on Graptolites by S.C. Hsü, 275-324, Geol. Pub. House, Beijing, China.

Yu Jianhua, Fang Yiting \& Liu Huaibao 1982: The Early Ordovician Xinchangian graptolite-bearing strata from Wuning, Jiangxi, Acta Sci. Nitur. Univ. Nankinensis, 2, 478487.

Yu Jianhua, Liu Huaibao \& Fang Yiting 1984: Anisograptidae of the Xinchangian Age (Early Ordovician) from the Xiushui Drainage Basin, Jiangxi, Acta Palaeont. Sinica, 23 (5), 532-542.

Yu Jianhua, Liu Huaibao \& Fang Yiting 1985: Dendroids from the Xinchangian stage (Early Ordovician) of the Xiushui Drainage Basin, Jiangxi Province, Acta Palaeont. Sinica, 24(1), 18-28.

Zhao Xianglin 1983: Early Xinchangian (x1) dendroids from Benxi, Liaoning, Acta Palaeont. Sinica, 22(4), 370-385.

Zhao Xianglin \& Chen Lunsheng 1984: The Cambrian-Ordovician boundary in Benxi, Liaoning, Jour. Stratigr., 8(2), $115-119$.

Zhao Xianglin and Zhang Shunxin 1985: Reclined Graptolites of the Xinchangian, Jour. Changchun College Geol, 40(2), $13-26$.

Zhao Xianglin and Zhang Shunxin 1986: On discovery of Psigraptus in China, In Palaontological Soc. China (eds): Selected papers from the 13th and 14th annual conventions of Palaeontological Society of China, 79-89. 